\title{
The Qualifications and Views of Instructors in the Distance Education System
}

\author{
https://doi.org/10.3991/ijet.v16i22.26067 \\ Blerta Prevalla Etemi ${ }^{1(\bowtie)}$, Teymur E. Zulfugarzade ${ }^{2}$, Natalia L. Sokolova ${ }^{3}$, \\ Viktoriia V. Batkolina ${ }^{4}$, Natalya I. Besedkina ${ }^{5}$, Regina G. Sakhieva ${ }^{6}$ \\ ${ }^{1}$ AAB College, Prishtina, Republic of Kosova \\ ${ }^{2}$ Plekhanov Russian University of Economics, Moscow, Russia \\ ${ }^{3}$ Peoples' Friendship University of Russia (RUDN University), Moscow, Russia \\ ${ }^{4}$ Russian New University (RosNOU), Moscow, Russia \\ ${ }^{5}$ Financial University Under the Government of the Russian Federation, Moscow, Russia \\ ${ }^{6}$ Federal University, Kazan, Russia \\ blerta.prevalla@universitetiaab.com
}

\begin{abstract}
A new process has been brought about due to the COVID-19 pandemic that has affected the world. Due to the COVID-19 pandemic, since the spring semester of the 2019-2020 academic year, all education and courses are provided through distance education. Therefore, since distance education is a new process for many, faculty members may encounter various problems. For this reason, determining the views of lecturers about the distance education process is important for the improvement and development of the distance education system. The aim of this study is to examine the views of the lecturers who teach through the distance education system and to make suggestions for the improvement of the system. The situation was determined using the qualitative research method. The research questions were prepared by the researchers. Their validity was ensured by taking experts' opinions. For this purpose, interviews with semistructured questions were conducted with 28 instructors at Cyprus and Russian universities and the data obtained were evaluated by content analysis. The findings obtained as a result of the research are given in detail in the findings and results section.
\end{abstract}

Keywords-COVID-19, distance education, technology, online instructors, university, pandemic

\section{Introduction}

The epidemic, which started in the first spring of 2020 and came to be present in the city of Wuhan, China, has affected all areas of life. The COVID-19 pandemic, often defined as a coronavirus disease, is also referred to as the novel coronavirus 2019 (World Health Organization [WHO], 2020); [7]. The WHO, while defining COVID19 , defined it as a dangerous and threatening disease in the world. This epidemic was declared a pandemic by the World Health Organisation on March 1, 2020 [7]. The COVID-19 pandemic, affecting global health, quickly spread globally [12] and had 
very serious and unexpected consequences. These problems are biological, psychological, social, spiritual and economic [27].

This pandemic, which has affected the world, has also negatively affected the field of education. There have been complete closures in countries due to the pandemic. The situation in general education in countries, namely face-to-face education, has completely changed since the spring of 2020, when the first coronavirus case was seen [4] [35] [36]. Universities are experiencing an unprecedented 'migration' from traditional classroom face-to-face education to online education. Due to the spread of the coronavirus disease (COVID-19) in China, most Chinese universities have started online education following the government's 'non-stop teaching and learning' requirements. In a short time, many faculty members began to teach via computers and students had to take online courses from their homes. Beyond China, with the worldwide spread of COVID-19, as of March 13, 61 countries in Africa, Asia, Europe, the Middle East, North America and South America have announced or implemented school and university closures, and most universities have become mandatory. Localization was closed [31].

Continuing education online, from face to face, has brought about many problems with it. The COVID-19 pandemic and its consequences have caused serious problems for many individuals [3]. Universities are among the institutions affected by the epidemic [1] [6] [9] [23] [24]. It was also investigated that university students experienced various problems during the COVID-19 pandemic [34].

It will come with training names prepared with digital tools and equipment. They are distance education, open education, flexible education and co-education, to name a few. Training given over the Internet is the most widely used term for all information and communication technologies. Based on information and communication technologies for learning conditions and learning digital tools, the concept is named as 'e-learning' or 'distance education' [15]. The most widely used term among them is e-learning. E-learning is a common term used to describe and encompass the digital learning technologies process (Nichols, 2008). In addition to online education (online) and e-learning, the concept of distance education has also been widely used in digital education [24]. Distance education is the main structure of online learning. Interactions between students, teachers and educational resources in distance education require simultaneous actions. There is a concern among some educators that distance learning is jeopardising education. Educators related to distance education have some concerns. Education quality may not be as effective as face-to-face education like all Internet-based online courses and organised courses and programmes [13] [27] [35]. Likewise, educators worry that technology will simplify traditional education and destroy individual relationships [19]. In addition, there are researchers who argue that there is no difference between traditional education and distance education. The validity of most studies involving online comparisons and the lack of traditional learning (Russell, 1999) has been questioned by researchers. In particular, Lockee, Moore and Burton (2001, p. 62) believe that 'there is no significant difference between face-to-face interviews. Face-toface education and distance learning do not mean they are equally good or bad' [21]. 
Due to the COVID-19 pandemic, all education units have switched to online education including universities, primary schools, secondary schools and high schools, special education schools etc. So, were we ready for distance education? Students and instructors entered the process of being ready for online education quickly. This process was more difficult for people without a socio-economic status [27]. It is suitable for education and teaching staff for training (open education) at a training point, and it is also a guide for trainers and students [2]. In addition, teachers are the people who will ensure that the education received will be effective in distance education such as the face-to-face education [14]. Distance education is a form of physical education delivered remotely. According to Lee [15], online education is an educational approach given through social learning and learning knowledge. Technologies allow communication between instructors and students through casual interaction. Most online instructors/academics have little experience with many subjects alike with students [22] [28].

Liu et al. [16] reported that the internet is active and the user interface allows students to perceive online education positively. On the contrary, online education may lead instructors and students to resort to illegal and unethical plagiarism (Ubell, 2017). Lucky et al. [18] determined that the rate of students who resort to academic plagiarism in online education is much higher than in face-to-face education. In addition, according to the results of some studies, there is no significant difference between the learning environments in online and face-to-face education [2] [5]. Certain online education factors, such as quality, flexibility, communication, responsiveness, and technical support services, influence and positively change students' views on online education [11].

Paechter and Maier [20] compared online learning with face-to-face learning in their study. As a result of the study, it was obtained that the students' perceptions of online learning were positive. For this reason, face-to-face classes have long been a challenging process, and the application of high standards of integrity in online education should be taken seriously, as evidenced by the results of decades of studies [25] [33]. Authors of some studies [27] [29] found online education to be one of the most important learning facilitators for some students, while for others it was the most important barrier in the COVID-19 process. Especially during the COVID-19 pandemic, there is a greater need for online-offline (distance) education. This raises the question of whether nations and colleges have online (distance) education infrastructure qualifications ready. Distance education activity tools offered in pre-university education institutions or universities in the countries differ. This demonstrates that the quality of online courses varies between online education providers and service-providing countries [15]. For this reason, the researchers suggested that due to the unprepared transition to online or distance education during the COVID-19 pandemic, educational institutions should pay attention to the above-mentioned factors, provide flexibility to students and instructors, have their prior knowledge ready, and raise awareness. Studies are needed to provide technical education support to online or distance education services more efficiently. 


\subsection{Purpose of the study and research questions}

The answers to the following questions were sought in order to determine the opinions and suggestions of academicians teaching at the university towards distance education platforms:

1. How would you describe the transition process to distance education?

2. Could you prepare your lessons in accordance with the distance education system?

3. What is the difference between distance education and face-to-face education?

4. What are your opinions and suggestions about distance education?

\section{$2 \quad$ Method}

Interview and document analysis techniques, which are among the qualitative techniques, were used in the research conducted to determine the views and suggestions of the lecturers working at the university on distance education. A descriptive study was conducted with the interview method, which is one of the qualitative research methods. Qualitative data analysis is used to identify problems or suggestions in detail [17]. Mendelli [26] stated that the main feature of qualitative research is that it is a research model that helps us to understand the participants' own perspectives on a situation or topic, and their comments and suggestions on the subject.

\subsection{Data collection tools}

In order to reach the conclusion of the research, a demographic information form and semi-structured interview questions consisting of open-ended questions developed by the researchers were used as data collection tools. Expert opinions were taken in the finalization of the prepared interview questions, and after the opinions, four open-ended questions were used as data collection tools. The open-ended questions in the questionnaire were prepared using the literature and the researchers' own experiences. In order to determine the demographic characteristics of the trainers, their personal information was asked. In the preparation of the questions, first, five faculty members from the Computer and Instructional Technologies Department were interviewed, and experienced qualitative research experts reviewed the questionnaire and the final form was applied to the structures according to the feedbacks. In this case, a questionnaire was applied to six trainers from outside the study group for the pilot application and it was checked whether the questionnaire was understandable.

\subsection{Research group}

This study was carried out with the participation of 28 faculty members in the spring term of 2020-2021. Semi-structured interview questions were asked to the faculty members participating in the research and the results were analysed descriptively. The research working group consists of educators using the distance education platform. The results of the survey revealed teachers' positive and negative views about distance 
education competencies, perspectives on distance education and technology information.

Table 1. Demographic information of the instructors

\begin{tabular}{|l|c|c|}
\hline \multirow{3}{*}{ Gender } & & f \\
\hline \multirow{3}{*}{ Country } & Female & 17 \\
\cline { 2 - 3 } & Male & 11 \\
\cline { 2 - 3 } & Total & 28 \\
\cline { 2 - 3 } & Cyprus & 15 \\
\cline { 2 - 3 } & Russia & 13 \\
\hline
\end{tabular}

\section{$3 \quad$ Results}

\subsection{The transition process of educators to distance education}

The answers given by the instructors regarding the transition to distance education are shown in Table 2.

Table 2. Transition process of educators to distance education

\begin{tabular}{|l|c|c|}
\hline & Theme & f \\
\hline \multirow{4}{*}{ Those caught off guard } & Insufficient infrastructure & 13 \\
\cline { 2 - 3 } & Lack of system knowledge & 10 \\
\cline { 2 - 3 } & Problem with content creation & 8 \\
\cline { 2 - 3 } & School preparation process & 7 \\
\hline Those who are ready & & 1 \\
\hline
\end{tabular}

The views of university lecturers about the transition to distance education are generally negative. The opinions of the faculty members working at the university on the transition to distance education were asked. In this context, they stated that their distance education system knowledge was insufficient. Again, most lecturers stated that they had great problems in designing content during the transition to distance education. Some lecturers, on the other hand, stated that they had problems due to the lack of sufficient infrastructure in the transition process of the university to distance education and that they started education late. One faculty member stated that he did not have any problem in the transition to distance education due to the fact that both the university and he had sufficient infrastructure and knowledge.

\subsection{Preparing lessons in accordance with the distance education system}

The question of How did you adapt the course contents to the distance education system was asked to the teachers. The answers are given in Table 3. 
Paper-The Qualifications and Views of Instructors in the Distance Education System

Table 3. Preparing lessons in accordance with the distance education system

\begin{tabular}{|l|c|}
\hline Theme & $\boldsymbol{f}$ \\
\hline PowerPoint & 17 \\
\hline PDF document & 11 \\
\hline Video & 4 \\
\hline Screen sharing & 2 \\
\hline
\end{tabular}

The answers regarding the question of how do you prepare the course contents for the faculty members at the university in distance education are given in Table 3 . When the answers given by the lecturers are examined, it is seen that they designed the course content in an ordinary traditional way. The answers given by the teachers stated that they prepared the course content topics on PowerPoint. There were also lecturers who shared content topics in PDF format. In addition to these answers, it is noteworthy that the number of lecturers who shared videos and screens is quite low.

\subsection{Differences between distance education and face-to-face education}

Instructors (in Table 4) were asked about the differences between distance education and face-to-face education. The answers to this finding were categorised as advantages and disadvantages. When looking at the advantages of distance education, place does not matter (10), delivering technology-supported education (8) and online lessons programme schedules (5) were listed. Considering the advantages of face-to-face education, high student-teacher interaction (20), instant question and answer opportunity in the classroom (8) and student check-up (6) were listed. When looking at the findings regarding the disadvantages of distance education, technical structure problem (10), very little student-teacher interaction (8), low motivation (6), Internet outage problem (6) and online lessons programme schedules (2) were listed. Considering the disadvantages of face-to-face education, the impossibility of rewatching the course (21) and being at a specific place and time (7) were listed.

Table 4. Difference between distance education and face-to-face education

\begin{tabular}{|c|c|c|}
\hline & Advantage & Disadvantage \\
\hline \multirow{5}{*}{$\begin{array}{l}\text { Distance } \\
\text { education }\end{array}$} & Place does not matter (10) & Technical structure problem (10) \\
\hline & Delivering technology-supported education (8) & Very little student-teacher interaction (8) \\
\hline & Online lessons programme schedules (5) & Low motivation (6) \\
\hline & & Internet outage problem (6) \\
\hline & & Online lessons programme schedules (2) \\
\hline \multirow{3}{*}{$\begin{array}{l}\text { Face-to-face } \\
\text { education }\end{array}$} & High student-teacher interaction (20) & $\begin{array}{l}\text { The impossibility of rewatching the course } \\
\text { (21) }\end{array}$ \\
\hline & $\begin{array}{l}\text { Instant question and answer opportunity in the } \\
\text { classroom (8) }\end{array}$ & Be in a specific place and time (7) \\
\hline & Student check-up (6) & \\
\hline
\end{tabular}




\subsection{Opinions and suggestions about distance education}

The university lecturers were asked for their opinions and suggestions about distance education. 25 lecturers stated that it cannot replace face-to-face education. There are 12 lecturers who stated that distance education can be a tool to support face-to-face education. 12 instructors stated that their knowledge about distance education is insufficient. Most of the lecturers stated that they needed training related to distance education. During the education period, certificate programmes were organised for both students and teachers. Lecturers stated that they should take it.

\section{$4 \quad$ Results and discussion}

To achieve this goal, our aim is to contribute to education about transition to education. According to the programmes obtained from this research, opportunities related to the appropriate education system can be provided. Repeatedly, members stated that their greatest difficulty was content design during the transition to distance education. Some students, on the other hand, faced difficulties in order to pass from benefiting from the university's transition to education process. One student did not experience any problem in transitioning to any education due to the fact that both the university and he had sufficient knowledge. The result obtained from this finding does not coincide with the result of Lee's [15] study. Lee [15], in his study, stated that online education is an educational approach given through social learning and learning information. Technologies allow communication between instructors and students through everyday interaction. Most online instructors/academics have little experience with many similar subjects with students. This result is surprising. It is to give an idea about the positive impression of only 1 out of 28 lecturers.

Instructors' ways of preparing course content materials were asked and the results of this finding are again surprising. The answers given by the teachers stated that they prepared the course content topics on PowerPoint. It is seen that there are faculty members who share the content topics in the PDF format. In addition to these answers, it is noteworthy that the number of lecturers who shared videos screens is quite low. There are many contents design models in the distance education system. And it is very sad that only PowerPoint, PDF files and screen sharing are made use of as content and other models are not known. One of these categories is private content knowledge, which has mastery of the basic concept and content of the private field that the teacher will teach [38] [39]. Another is general knowledge about the profession, i.e., how the teacher teaches. Student recognition, material development, classroom management, strategy and method measurement and evaluation include knowledge and skills [37].

The instructors were asked about the differences between distance education and face-to-face education. In order to analyse the answers in detail, the answers to this finding are discussed separately as advantages and disadvantages. Considering the advantages of distance education, location does not matter (10), technology-supported education (8) and online curriculum schedules (5) were listed. Considering the advantages of face-to-face education, high student-teacher interaction (20), instant question and answer opportunity in the classroom (8) and student checks (6) were listed. 
Considering the findings regarding the disadvantages of distance education, technical problems (10), very little student-teacher interaction (8), low motivation (6), Internet interruption problem (6) and online curriculum schedules (2) were included. Considering the disadvantages of face-to-face education, the impossibility of watching the lesson again (21) and being at a certain place and time (7) were included. When the answers to the disadvantages of distance education are examined, it can be said that there are disadvantages due to the limited knowledge of the instructors about distance education [26]. The desire for internationalization, flexibility in education and the spread of online education in these subjects require the instructors to keep up with these developments and to encourage the change of field knowledge by using web-based technological tools.

According to the results of the findings regarding the opinions and suggestions of university faculty members about distance education, 25 faculty members stated that it cannot replace face-to-face education. Although we live in the age of digital natives in the technological age, it is very sad that negative opinions about distance education are reported. There are 12 faculty members who stated that distance education can be a tool to support face-to-face education. This is pleasing. Increasing technology-supported education means leaving the traditional education approach. 12 lecturers stated that their knowledge about distance education is insufficient. Most of the lecturers stated that they need training related to distance education. These results are supported by the answers given to other findings. It can be said that the lecturers have a lack of knowledge about system information, system usage information and content preparation information. This situation can be corrected with training. On the other hand, Celen et al. [4] found that distance education lags behind traditional face-to-face education and attitudes towards distance education are negative. In a similar study, academics emphasized that 'high-level skills' cannot be measured in distance education; therefore, assessments should be made face to face [30]. In another study, it was concluded that a significant portion of the students participating in postgraduate education programmes came from outside the city and it was beneficial because the concept of space was significantly removed with distance education [8] [16].

\section{$5 \quad$ Suggestions}

It is the institution that provides high-level cognitive skills in university educational institutions. Educational perspectives of university lecturers are very important. We live in a technological age. The concept of distance education, which is the biggest example of technology use in education, is very important. The perspectives and views of the university lecturers towards distance education, which is one of the technologically supported educations, are very thought-provoking. Instructors need training in the field of distance education. They also need training in computer usage. In order to change the views of the instructors, their perspectives can be changed by giving them in-service trainings. It is suggested that instructors be encouraged to include more technology-supported tools in their lessons. This study was conducted in Russia and Cyprus. The same study can be carried out and comparisons can be made with the lecturers 
working at universities in other countries. The same study can be carried out with students who have master's and doctorate degrees at universities. And the views of future academics and today's academics on distance education can be compared. Instructors can be given distance education trainings and it can be checked whether their perspectives on distance education change before and after the education.

\section{References}

[1] Akyol, G., Baskan, A. H., \& Baskan, A. H. (2020). Yeni tip koronavirus (COVID-19) doneminde spor bilimleri fakultesi ogrencilerinin karantina zamanlarinda yaptiklari etkinlikler ve sedanter bireylere onerileri. Avrasya Sosyal ve Ekonomi Arastirmalari Dergisi, 7(5), 190203. https://doi.org/10.47998/ikad.788255

[2] Allen, I. E., \& Seaman, J. (2008). Staying the course: Online education in the United States. The Sloan Consortium.

[3] Arslan, G. (2020). Loneliness, college belongingness, subjective vitality, and psychological adjustment during coronavirus pandemic: Development of the college belongingness questionnaire. Journal of Positive School Psychology, 1-15. https://doi.org/10.31234/osf.io/j7tf2

[4] Bhuyan, M., \& Tamir, A. (2020). Evaluating COs of computer programming course for OBE-based BSc in EEE program. International Journal of Learning and Teaching, 12(2), 86-99. https://doi.org/10.18844/ijlt.v12i2.4576

[5] Brown, B. W., \& Liedholm, C. E. (2002). Can web courses replace the classroom in principles of microeconomics? American Economic Review, 92(2), 444-448. https://doi.org/10. $\underline{1257 / 000282802320191778}$

[6] Cetin, C., \& Anuk, O. (2020). COVID-19 pandemi surecinde yalnizlik ve psikolojik dayaniklilik: Bir kamu universitesi ogrencileri orneklemi. Avrasya Sosyal ve Ekonomi Arastirmalari Dergisi, 7(5), 170-189. https://doi.org/10.19129/sbad.220

[7] Cucinotta, D., \& Vanelli, M. (2020). WHO declares COVID-19 a pandemic. Acta BioMedica: Atenei Parmensis, 91(1), 157-160.

[8] Fuada, S., Adiono, T., \& Prasetiyo, P. (2005). Accuracy improvement of RSSI-based distance localization using unscented kalman filter (UKF) algorithm for Wi-Fi tracking application. International Journal of Interactive Mobile Technologies (iJIM), 14(16), 225-233. https://doi.org/10.3991/ijim.v14i16.14077

[9] Gencalp, D. K. (2020). COVID-19 salgini doneminde ilk ve acil yardim ogrencilerinin beslenme aliskanliklari ve fiziksel aktivite durumlarinin degerlendirilmesi. Paramedik ve Acil Saglik Hizmetleri Dergisi, 1(1), 1-15. https://doi.org/10.33715/inonusaglik.628804

[10] Gonzalez, C. (2009). Conceptions of, and approaches to, teaching online: A study of lecturers teaching postgraduate distance courses. Higher Education, 57(3), 299-314. https://doi.org/10.1007/s10734-008-9145-1

[11] Helgesen, O., \& Nesset, E. (2007). Images, satisfaction and antecedents: Drivers of student loyalty? A case study of a Norwegian university college. Corporate Reputation Review, 10(1), 38-59. https://doi.org/10.1057/palgrave.crr.1550037

[12] Huang, C., Wang, Y., Li, X., Ren, L., Zhao, J., Hu, Y., ... Caot, B. (2020). Clinical features of patients infected with 2019 novel coronavirus in Wuhan, China. The Lancet, 395(10223), 497-506. https://doi.org/10.1016/S0140-6736(20)30183-5

[13] Kelkay, A. (2020). Teachers' role in curriculum implementation at primary and secondary schools of Addis Ababa, Ethiopia. Contemporary Educational Researches Journal, 10(2), 28-41. https://doi.org/10.18844/cerj.v10i2.4660 
[14] Lack, K. A. (2013). Current status of research on online learning in postsecondary education. ITHAKA S+R. https://doi.org/10.1093/gao/9781884446054.article.t042902

[15] Lee, J. W. (2010). Online support service quality, online learning acceptance, and student satisfaction. Internet and Higher Education, 13, 277-283. https://doi.org/10.1016/ j.iheduc. 2010.08 .002

[16] Liu, O. L. (2012). Student evaluation of instruction: In the new paradigm of distance education. Research in Higher Education, 53(4), 471-486. https://doi.org/10.1007/s11162-0119236-1

[17] Liu, S., Yang, L., Zhang, C., Xiang, Y. T., Liu, Z., Hu, S., \& Zhang, B. (2020). Online mental health services in China during the COVID-19 outbreak. The Lancet Psychiatry, 7(4), e17-e18. https://doi.org/10.1016/S2215-0366(20)30077-8

[18] Lucky, A., Branham, M., \& Atchison, R. (2019). Collection-based education by distance and face to face: Learning outcomes and academic dishonesty. Journal of Science Education and Technology, 28: 414-428. https://doi.org/10.1007/s10956-019-9770-8

[19] Eguz, S. (2020). Availability of virtual museum applications in courses based on the views of classroom teachers. Cypriot Journal of Educational Sciences, 15(2), 194-207. https://doi.org/10.18844/cjes.v15i2.4501

[20] Paechter, M., \& Maier, B. (2010). Online or face-to-face? Students' experiences and preferences in e-learning. Internet and Higher Education, 13, 292-297. https://doi.org/ 10.1016/j.iheduc. 2010.09.004

[21] Sabirli, Z. \& Coklar, A. (2020). The effect of educational digital games on education, motivation and attitudes of elementary school students against course access. World Journal on Educational Technology: Current Issues, 12(3), 165-178. https://doi.org/10.18844/ wjet.v12i3.4993

[22] Salama, R., Uzunboylu, H., \& El Muti, M. (2020). Implementing online questionnaires and surveys by using mobile applications. New Trends and Issues Proceedings on Humanities and Social Sciences, 7(3), 48-70. https://doi.org/10.18844/prosoc.v7i2.5016

[23] Saritas, E. \& Barutcu, S. (2020). Ogretimde dijital donusum ve ogrencilerin cevrimici ogrenmeye hazir bulunuslugu: Pandemi doneminde Pamukkale Universitesi ogrencileri uzerinde bir arastirma. Internet Uygulamalari ve Yonetimi Dergisi, 11(1), 5-22. https://doi.org/ 10.34231/iuyd.706397

[24] Seferoglu, S., \& Celen, F. (2020). Improving the use of ICT through online professional development platform based on metacognitive strategies. Global Journal of Information Technology: Emerging Technologies, 10(1), 45-59. https://doi.org/10.18844giit.v10i1.4747

[25] Stiles, B. L., Wong, N. C. W., \& LaBeff, E. E. (2018). College cheating thirty years later: The role of academic entitlement. Deviant Behav, 39(7), 823-834. https://doi.org/10.1080/ $\underline{01639625.2017 .1335520}$

[26] Talib, C. A. (2019). Enhancing students' reasoning skills in engineering and technology through game-based learning. iJET, 14(24), 69-80.

[27] Tanhan, A. (2020). COVID-19 surecinde online seslifoto (OSF) yontemiyle biyopsikososyal manevi ve ekonomik meseleleri ve genel iyi olus duzeyini ele almak: OSF'nin Turkceye uyarlanmasi. [Utilizing online photovoice (OPV) methodology to address biopsychosocial spiritual economic issues and wellbeing during COVID-19: Adapting OPV to Turkish.] Turkish Studies, 15(4), 1029-1086. https://doi.org/10.7827/TurkishStudies.44451

[28] Alipour, M., \& Tajfar, S. (2019). Investigating (Im)politeness in online forums between English speakers and English as a foreign language learners. Global Journal of Foreign Language Teaching, 9(3), 137-156. https://doi.org/10.18844/gjflt.v9i3.4205

[29] Tanhan, A., Yavuz K. F., Young, J. S., Nalbant, A., Arslan, G., Yildirim, M., ... Cicek, I. (2020). A proposed framework based on literature review of online contextual mental health 
services to enhance wellbeing and address psychopathology during COVID-19. Electronic Journal of General Medicine, 17(6), em254. https://doi.org/10.29333/ejgm/8316

[30] Tuncer, M., \& Tanas, R. (2011). Akademisyenlerin Uzaktan Egitim Programlarina Yonelik Goruslerinin Degerlendirilmesi (Firat ve Tunceli Universiteleri Ornegi). Ilkogretim Online, $10(2), 776-784$.

[31] UNESCO. (2020). UNESCO report, 'COVID-19 educational disruption and response'. https://en.unesco.org/covid19/educationresponse/

[32] Uzunboylu, H., \& Beheshti, M. (2017). An investigation through content analysis in infographics. The Turkish Online Journal of Design Art and Communication, 7(4), 655-666. https://doi.org/10.7456/10704100/011

[33] Vandehey, M. A., Diekhoff, G. M., \& LaBeff, E. E. (2007). College cheating: A twentyyear follow-up and the addition of an honor code. Journal of College Student Development, 48(4), 462-480. https://doi.org/10.1353/csd.2007.0043

[34] Viner, R. M., Russell, S. J., Croker, H., Packer, J., Ward, J., Stansfield, C., ... Booy, R. (2020). School closure and management practices during coronavirus outbreaks including COVID-19: A rapid systematic review. The Lancet Child \& Adolescent Health, 4(5), 397404. https://doi.org/10.1016/s2352-4642(20)30095-x

[35] Walker, P. G. T., Whittaker, C., Watson, O. J., Baguelin, M., Winskill, P., Hamlet, A., ... Ghani, A. C. (2020). The impact of COVID-19 and strategies for mitigation and suppression in low-and middle-income countries. Science, 369(6502), 413-422. https://doi.org/10.1126/ science.abc0035

[36] Hamdi, M., \& Hamtini, T. M. (2016). Designing an effective e-content development framework for the enhancement of learning programming. International Journal of Emerging Technologies in Learning, 11, 131. https://doi.org/10.3991/ijet.v11i04.5574

[37] Akbasli, S., Altun, T., Argon, T., Birel, F., Elma, C., Ergen, H. \& Genc, S. (2009). Egitim bilimine giris (K. Kiroglu \& C. Elma, Trans.). Pegem Akademi. https://doi.org/10.14527/ 9786055885946

[38] Konst, T., \& Kairisto-Mertanen, L. (2019). Developing innovation pedagogy. Contem-porary Educational Researches Journal, 9(3), 74-84. https://doi.org/10.18844/cerj.v9i3 $\underline{.4224}$

[39] Konur, K. B., Sezen, G., \& Tekbiyik, A. (2008). Fen ve teknoloji derslerinde yapilandirmaci yaklasima dayali etkinliklerde ogretim teknolojilerinin kullanilabilirligine yonelik ogretmen gorusleri. The 8th International Educational Technology Conference.

\section{$7 \quad$ Authors}

Blerta Prevalla Etemi PhD, is a lecturer at the Faculty of Computer Science at AAB College for more than 10 years, as well as a former dean and a former vice dean at the same Faculty. She is also the author of over 20 scientific papers in prestigious international journals.

Teymur E. Zulfugarzade is $\mathrm{PhD}$ in Law and Associate Professor in the Department of Civil Legal Disciplines at Plekhanov Russian University of Economics. His research interests are related to the legal support of economic and educational activities, the methodology of scientific articles and dissertations, mentoring and teaching and legal education and training. He has more than 500 published works in Russian and international journals (Email: teymurz@yandex.ru). 
Natalia L. Sokolova is a PhD in Philology, Associate Professor and Head of the Institute of Foreign Languages at Peoples' Friendship University of Russia (RUDN University). She is also the Head of the Department of Theory and Practice of Foreign Languages of the Institute of Foreign Languages at RUDN University. She is the developer of the author's lecture cycle for undergraduate programmes of the linguistics training direction in Russian and English and also of the educational programmes for students of linguistic and non-linguistic universities and faculties in the main and second foreign languages. She has more than 115 published papers in Russian and international journals (Email: n.sokolova@rudn.ru).

Viktoriia V. Batkolina is PhD in Education, Associate Professor and Chief Executive of the Institute of Pedagogy and Psychology of Russian New University. Her spheres of interests include innovative processes in education. She deals with the issues of education quality increase among adults by means of using modern informational technologies, as well as improving remote communicative connection between students and lecturers, the process of students' adaptation to university education conditions and modern models of effective education facility management. She is the author of more than 20 published scientific works (Email: batkolina@rosnou.ru).

Natalya I. Besedkina is a PhD in Law and Associate Professor in the Department of Legal Regulation of Economic Activity, Financial University under the Government of the Russian Federation. She actively studies the problems of adult education, teacher education and educational environment possibilities. She is the author of more than 60 scientific and educational works. The most significant ones are devoted to the problems of inheritance law, family law, civil law and problems of education (Email: nbesedkina@fa.ru).

Regina G. Sakhieva is a PhD in Education and Associate Professor in the Department of Pedagogy of Higher Education of the Institute of Psychology and Education at Kazan (Volga region) Federal University. Her research interests are related to the methodology of teacher education, educational programmes design and content selection. She has more than 100 published papers in Russian and international reputable journals (Email: saxievarg@mail.ru).

Article submitted 2021-08-06. Resubmitted 2021-09-15. Final acceptance 2021-09-15. Final version published as submitted by the authors. 